\title{
Evaluation of Oriental Pickling Melon (Cucumis melo L. Var. conomon) Genotypes for Pest and Disease Reaction under Northern Dry Zone of Karnataka
}

\author{
Shruti Prakash. Gondi (Corresponding author) \\ MSc. (Hort) Vegetable Science Department, College of Horticulture, University of \\ Horticultural Sciences, Bagalkot, India \\ E-mail: shrutigondi103@gmail.com
}

V. M. Ganiger

Professor, Vegetable Science Dept. MHREC, UHS Bagalkot, India

Tel: 91-990-022-1631

Bhuvaneshwari. G

Assistant Professor (Food and Nutrition), UHS, Bagalkot, India

Tel: 91-900-887-1581

M. B. Madalageri

Vegetable Science, Registrar, UHS, Bagalkot, India

Tel: 91-948-069-6389

Y. K. Kotikal

Dept of Entomology, DSW, UHS, Bagalkot, India

Tel: 91-944-987-2868

Manjunatha. G

Assistant Professor (Plant Pathology), UHS, Bagalkot 


\section{Macrothink Institute ${ }^{\mathrm{TM}}$}

Received: December 13, 2015 Accepted: December 19, 2015 Published: June 18, 2016

doi:10.5296/jee.v7i1.9630
Journal of Environment and Ecology

ISSN 2157-6092

2016, Vol. 7, No. 1

\begin{abstract}
Cucurbits are the group of vegetables belongs to the family Cucurbitaceae. Oriental pickling melon (Cucumis melo var. conomon) is one among the melon group vegetables belongs to Cucurbitaceae family with a chromosomal number $2 \mathrm{n}=24$. It is also called as golden melon or culinary melon in English. In Karnataka it is called by local names as Sambar Southe, Mogghe kayi or Mangalore southe. A field experiment was carried out at University of Horticultural Sciences Bagalkot, Karnataka to study the reaction of oriental pickling melon to fruit fly pest, diseases like powdery mildew and downy mildew disease. The results revealed that least infestation of fruit fly was recorded in Sirsi Local $(40.00 \%)$ followed by BCMCO-01 (41.30\%), BCMCO-02 and BCMSO-03 (41.75\% each). Highest infestation of fruit fly was recorded in Sirsi-2-13 (65.07\%) followed by BCMSO-04 (59.90\%). Among the genotypes, none of them had showed resistant to infestation and found susceptible to fruit fly attack in unsprayed condition. Least infestation of powdery mildew was found in Mysore Local $(37.71 \%$ ) followed by Sirsi Local (37.99 \%) and BCMSO-03 (39.76 \%). Whereas highest mildew in GR-3 (46.08 \%) followed by Sirsi-1-13 (45.81\%) and BCMCO-02 $(45.75 \%)$. Least infestation of downy mildew was observed in BCMCO-02 (14.00\%) followed by Sirsi Local (16.29 \%) and BCMSO-03 (17.43\%). Highest infestation was found in GR-2-1 (27.07\%) followed by GR-4 (26.58 \%) and GR-4-1 (26.23 \%). Most of the genotypes were moderately susceptible to downy mildew disease.
\end{abstract}

Keywords: Disease, Genotypes, Infestation, Oriental pickling melon, Pest, Reaction 


\section{Introduction}

Cucurbits are the group of vegetables belongs to the family Cucurbitaceae. Oriental pickling melon (Cucumis melo var. conomon) is one among the melon group vegetables belongs to Cucurbitaceae family with a chromosomal number $2 n=24$. It is also called as golden melon or culinary melon in English. In Karnataka it is called by local names as Sambar Southe, Mogghe kayi or Mangalore southe. Fruits are varying in size, small to medium and big fruits with smooth tender skin, white flesh usually with little sweetness and odour. In view of current trend of expanding the cultivation of oriental pickling melon crop for their delicious vegetable fruits, identification of promising genotypes is prime importance as a commercial crop for the area with resistance to pest and diseases and quality fruits would help the farmers in its adoption and improving their economic status. In Karnataka, the crop is cultivated under limited area using mostly local varieties which are low in productivity. Towards this end, as a first step there is a need for collection of local genotypes and evaluate them for their adoptability to particular locations especially to their non traditional areas like Northern dry zone of Karnataka. Cucurbit fruit fly (Bactrocera cucurbitae) is one of the most important pests of cucurbits, which damage the crop to large extent. Because of the difficulties associated for the control of this pest by chemical insecticides, farmers experienced great losses in cucurbits. Powdery mildew is a widespread and often production limiting disease of oriental pickling melon(Cucumis melo L. conomon). Resistance against it is one object of many breeding programs. For many years the incitant fungus was considered to be Erysiphe cichoracearum . But all recent reports, however, indicate Sphaerotheca fuliginea Poll. as the incitant. Cucurbit downy mildew is one of the devasting disease worldwide. Therefore, a study on reaction of oriental pickling melon genotypes to fruit fly incidence, powdery mildew (Spaerotheca fulginiae) and downy mildew (Pseudoperonospora cubensis) disease was carried out under field conditions to assess the reaction of the melon genotypes to the northern dry zone of Karnataka.

\section{Materials and methods}

The field experiment on pest and diseases reaction studies in oriental pickling melon (Cucumis melo var. conomon) was conducted at separate isolated plot in Udyangiri, UHS Bagalkot Karnataka under no plant protection measures. Bagalkot is located in Northern dry zone (Zone-3) of Karnataka state at $16^{\circ} 10$ - North latitude, $75^{\circ} 42$ - East longitudes and at an altitude of $542.00 \mathrm{M}$ above the mean sea level. Bagalkot which comes under zone-3 of region-2 has benefits of both South-West and North-East monsoons. The average rainfall of South-West monsoon is about $360 \mathrm{~mm}$, distributed over a period of four months (June to September). The average rainfall of North-East monsoon is about $136 \mathrm{~mm}$.

The experiment was laid out with 24 treatments (genotypes). Each genotype in each replication was represented by a plot of single row of $4 \mathrm{~m}$ length with 4 plants per treatment. The seeds were sown at distance of two meter between the rows and one meter between the plants within the row. The recommended dosage of $\mathrm{N}, \mathrm{P}_{2} \mathrm{O}_{5}$ and $\mathrm{K}_{2} \mathrm{O}$ (100:75:50 kg per hectare) was applied in the form of urea, single super phosphate and muriate of potash, respectively. Even the application of vermicompost was also carried out to make the soil well 
fertile. Twenty days after sowing, the plants were thinned to retain one plant per hill. The weed flora of the experimental area was hand weeded thrice at 20, 40 and 60 DAS. First watering was given with rose can after sowing and the pits were daily watered in the same way till the seedlings emerged. The data on various observations such pest and disease reaction were tabulated and subjected to statistical analysis as described by Sunder Raj et al. (1972). Statistical significance of variation due to genotype was analysed through web agri stat package (WASP) by comparing the calculated values to Table ' $F$ ' values at five per cent level of significance. Figures in the parentheses are arc sine transformed values.

\section{Fruit Fly Incidence}

Per cent incidence of fruit fly damage was studied during rabi season in a separate experimental block. The number of fruits infested by fruit fly were counted and expressed as percentage of total fruits. Further, the genotypes were grouped in to different categories based on per cent fruit infestation (Babu, 2002) as given below.

\section{Fruit fly incidence reaction category}

\begin{tabular}{|c|c|}
\hline $\begin{array}{c}\text { Fruit } \\
\text { infestation }(\boldsymbol{\%})\end{array}$ & Reaction category \\
\hline $0-10$ & Resistant \\
\hline $11-25$ & Moderately resistant \\
\hline $26-50$ & Moderately Susceptible \\
\hline $51-75$ & Susceptible \\
\hline$>75$ & Highly susceptible \\
\hline
\end{tabular}

\section{Powdery mildew and downy mildew incidence (\%)}

The percentage of powdery mildew and downy mildew disease incidence was recorded as per cent leaf area infected for all the genotypes, which were scored following zero to five disease rating scale (Girisha, 1989) as given below.

\section{Scoring technique followed in powdery mildew and downy mildew incidence}

\begin{tabular}{|c|c|}
\hline Damage score & Extent of Damage \\
\hline 0 & No disease symptoms. \\
\hline 1 & $\begin{array}{l}\text { 1-10\% disease not visible, very few leaves per plant found diseased after } \\
\text { careful search. }\end{array}$ \\
\hline 2 & $11-25 \%$ disease visible in each direction, but most of leaves look healthy. \\
\hline 3 & $26-50 \%$ both diseased and healthy leaves are equally observed. \\
\hline 4 & $51-75 \%$ disease seen very easily with only some healthy leaves. \\
\hline 5 & $\begin{array}{l}\text { 76-100\% almost all leaves are diseased, with few healthy units are seen on } \\
\text { careful search. }\end{array}$ \\
\hline
\end{tabular}


Sum of individual rate in each scale

Disease severity $(\%)=$ x 100

No. of samples x maximum scale used

\section{Results and Discussion}

In the present research conducted, results were found non significant with respect to fruit fly incidence on oriental pickling melon genotypes (Tab.1). The per cent incidence ranged between 63.88 and 41.66. Among the genotypes the least infestation of fruit fly was recorded in Sirsi Local (40.00 \%) followed by BCMCO-01 (41.30\%), BCMCO-02 and BCMSO-03 (41.75\% each). Highest infestation of fruit fly was recorded in Sirsi-2-13 (65.07\%) followed by BCMSO-04 $(59.90 \%)$. Higher the fruit rind thickness lesser will be the fruit fly infestation. The fruits with less fruit rind thickness were susceptible to fruit fly infestation. In the initial stage of female flower opening, flower buds were attacked by fruit fly. However, released genotypes like Soubhagya and Mudicode were found to be most affected genotypes as compared to other genotypes. Resistance to fruit fly infestation in melons has also been reported by other scientists like Sapkota et al. (2012) and Shivaprasad (2013) in musk melon.

The oriental pickling melon genotypes did not differ significantly with respect to powdery mildew disease incidence (Tab.1). However, the incidence was less in genotypes like Mysore Local, Sirsi Local and Thirthalli Local. Least infestation was found in Mysore Local (37.71 \%) followed by Sirsi Local (37.99 \%) and BCMSO-03 (39.76\%). Whereas highest mildew was noticed in GR-3 (46.08 \%) followed by Sirsi-1-13 (45.81\%) and BCMCO-02 (45.75\%). The incidence of downy mildew disease was also least. Most of the genotypes were categorized under resistant category for downy mildew incidence. Among the genotypes BCMCO-02 (14.00 \%), Sirsi Local (16.29 \%) and BCMSO-03 (17.43\%) had shown moderately resistance to the disease. These genotypes were on par with each other. Highest infestation was found in GR-2-1 (27.07\%) followed by GR-4 (26.58 \%) and GR-4-1 $(26.23 \%)$. This might be due to grand growth stage coincidence with less temperature coupled with high relative humidity and genotypic performance resulted in occurrence of diseases. Apart from the leaf wetness essential for infection, the factors determining disease progress are: rate of foliage growth and physiological age of the host; amount of primary inoculum available, light, and the rate at which lesions necrotize. The interaction of these factors is described for early, mid-season, and late crops. Losses caused by $P$. cubensis depend on the growth stage at which the crop is attacked, and on the rate of foliage and pathogen development. Similar findings were opined by Zatkyo et al. (1982), Pandey et al. (2008), Margaret et al. (2012) and Pitchaimuthu et al. (2012) in musk melon.

Table 1. Pest and disease incidence of different oriental pickling melon genotypes

\begin{tabular}{|c|c|c|c|}
\hline Genotypes & $\begin{array}{c}\text { Fruit fly } \\
\text { incidence } \\
(\boldsymbol{\%})\end{array}$ & $\begin{array}{c}\text { Powdery } \\
\text { mildew } \\
\text { incidence }(\boldsymbol{\%})\end{array}$ & $\begin{array}{c}\text { Downy mildew } \\
\text { incidence (\%) }\end{array}$ \\
\hline $\mathrm{T}_{1}-$ Sirsi Local & $41.66(40.00)$ & $37.91(37.99)$ & $8.23(16.29)$ \\
\hline
\end{tabular}




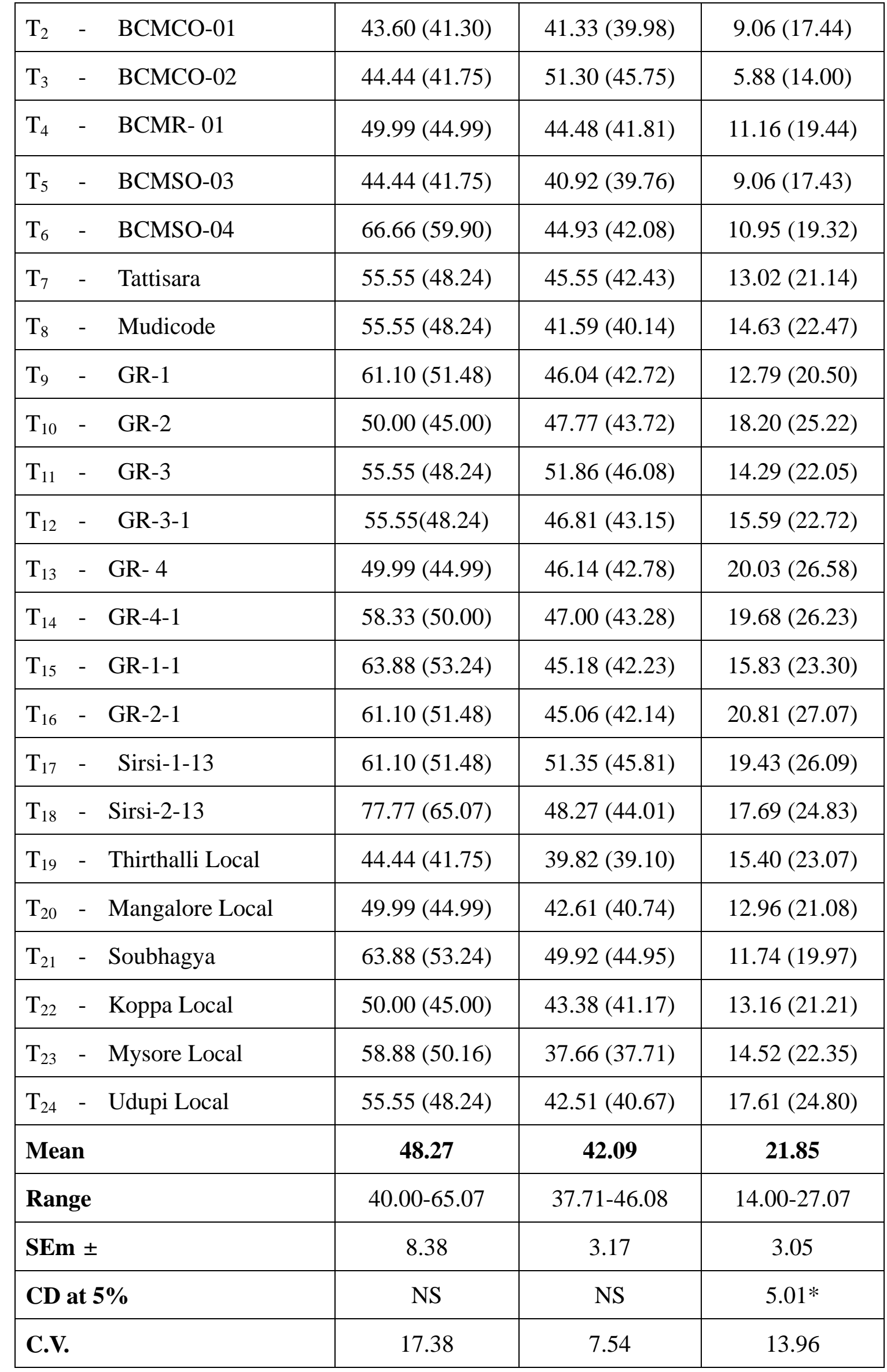


*Significant at $\mathrm{p}=0.05$

Note: Figures in the parentheses are arc sine transformed values

\section{Conclusion}

From the foregoing discussion it would be concluded that among the 24 oriental pickling melon genotypes tested for their performance for fruit fly incidence under northern dry zone of Karnataka, the genotypes viz., Sirsi Local followed by BCMCO-01 BCMCO-02 and BCMSO-03 were found with least infestation of cucurbit fruit fly. However, the powdery mildew incidence was less in genotypes like Mysore Local, Sirsi Local and Thirthalli Local. Among the genotypes BCMCO-02, Sirsi Local and BCMSO-03 had shown moderately resistance to the downy mildew disease. These genotypes were found better compared to the released (Kerala varieties) varieties which could be used as source for further crop improvement programme.

\section{References}

Agarwal, M. L., Sharma, D. D., \& Rahman, O. (1987). Melon fruit fly and its control. Indian Hort., 32, 10-11.

Babu, K. S. (2002). Species complex and population dynamics of fruit flies on some fruit and vegetable crops. M.Sc. (Agri.) Thesis, University of Agricultural Sciences, Dharwad.

Choi, I. Y., \& Cheong, S. S. (2015). First report of powdery cildew Cause by Podosphaera xanthii on oriental pickling melon in Korea. Plant Disease, 99, 730.

Cohen, Y., Baider, A., Petrov, L., Sheck, L., \& Voloisky, V. (1996). Cross-infectivity of Sphaerotheca fuliginea to watermelon, melon, and cucumber. Acta Hort. 510: VII Eucarpia Meeting on Cucurbit Genetics and Breeding.

Dhiman, J. S., Tarsem, L., \& Bajaj, K. L. (1995). Evaluation of muskmelon (Cucumis melo L.) genotypes for multiple disease resistance, yield and quality characteristics. Trop. Agric., 72, 58-62.

Frolov, V. V. (1981). Breeding melons for resistant to powdery mildew. Referafivnyi Zhurnal, 9(65), 277.

Girisha, K. N. (1989). Studies on biological control of powdery mildew pathogens with Cladosporium spp., M.Sc. (Agri.) Thesis, University of Agricultural Sciences, Bangalore.

Gupta, J. N., \& Verma, A. N. (1978). Screening of different cucurbits crops for the attack of the melon fruit fly, Dacus cucurbitae coquilett (Diptera: Tephritidae). Haryana J. Hort. Sci., 7, 78-82.

Lall, B. S., \& Sinha, S. N. (1959). On the biology of melon fly (Solanum melongena L.). Veg. Sci., 5: 89-92.

Margaret T. M., LaMarsh, K., \& Menasha, S. (2012). Powdery mildew-resistant melon variety evaluation, New York - 2012. Midwest Vegetable Trial Report for 2012. 
Mitchell, J. M., Cantliffe D. J. \& Sargent, S. A. (2006). Fruit yield, quality parameters and powdery mildew (Sphaerotheca fulginea) susceptibility of speciality melon (Cucumis melo L.) cultivars grown in a passively ventilated greenhouse. Cucurbitaceae, pp. 483-491.

Pandey, K. K., Singh, B., Gupta, R. C., Rai, A. B., \& Rai, M. (2008). Evaluation of cucumber (Cucumis sativus) genotypes against downy mildew, Veg. Sci., 35(2), 197-198.

Pitchaimuthu, M., Souravi, K., Girija Ganeshan, G., Santosh Kumar \& Pushpalatha, R. (2012). Identification of sources of resistance to powdery mildew and downy mildew diseases in cucumber [Cucumis sativus (L.)]. Pest Manage. Hort. Ecosys., 18, 105-107.

Sapkota, R., Dahal, K. C. \& Thapa, R. B. (2012). Damage assessment and management of cucurbit fruit flies in spring-summer squash. J. Entomol. Nematol., 2(1), 007-012.

Shivarkar, D. T., \& Dumbre, R. B. (1985). Bionomics and control of melon fruit fly. $J$. Maharashtra Agric. Univ., 10, 268-300.

Sowell, G. J., \& Corley, W. L. (1974). Severity of race 2 of Sphaerotheca fuliginea on muskmelon introductions reported resistant to powdery mildew. Hort. Sci., 9(4), 398-399.

Sunder Raj, N., Nagaraju, S., Venkataramu, M. N., \& Jaganath, M. K. (1972). Design and analysis of field experiments .M.Sc. Series No. 22, University of Agricultural Sciences, Bangalore.

Takada, K., Kanazawa, K., Takatuka, K., \& Takatsu, K., (1974). Studies on breeding for resistant to powdery mildew in melon I varietal differences in resistance and the breeding of the variety Sunrise. Bull. Veg. Orna. Crop Res. Station, 1, 59-91.

Thomas, C. E., Cohen, Y., McCreight, J. D., Jourdain, E. L., \& Cohein, S. (1988). Inheritance of resistance to downy mildew in Cucumis melo. Plant Disease, 73, 33-35.

Waraitch, K. S., Munshi, G. D., Nandpuri, K. S., \& Lal, T. (1977). Screening of muskmelon, wild melon and snapmelon for resistance to powdery mildew (Sphaerotheca fuliginea). Phytopath. Medt., 16(1), 37-39.

Yuko, S., \& Igorashi, I., (1974). Melon breeding ii. Kurume No.2 a melon selection combining resistance to powdery mildew and fusarium wilt. Bull. Veg. Orn. Crop. Res. Station, 1, 29-38.

Zatkyo, L. N. E. (1982). Breeding melon resistant to powdery mildew. Zoldsegtermesztesi Kutato Interzet Bulletinje., 15, 97-101.

\section{Copyright Disclaimer}

Copyright for this article is retained by the author(s), with first publication rights granted to the journal.

This is an open-access article distributed under the terms and conditions of the Creative Commons Attribution license (http://creativecommons.org/licenses/by/3.0/). 